\title{
Novel Three Phase Five Level Inverter with Reduced Number of Power Electronics Components
}

\author{
M.Kalaivani ${ }^{1}$, K.Deenu ${ }^{2}$ \\ ${ }^{I}$ (Applied Electronics, Dr. Mahalingam college of engineering and technology/Autonomous, India) \\ ${ }^{2}$ (Applied Electronics, Dr. Mahalingam college of engineering and technology/Autonomous, India)
}

\begin{abstract}
Novel three phase five level inverter with reduced number of power electronics components are introduced. This inverter consists of typical three phase two level-bridge inverter with three bidirectional switches and two cascaded $h$ bridge is added into the inverter. Fundamental frequency Staircase modulation technique is used to giving the switching gate signals to the novel three phase five level inverter. Novel three phase five level inverter is compared with conventional three phase five level inverter topologies. Simulation and results of proposed inverter is given.
\end{abstract}

Keywords- Bidirectional switches, cascaded h bridge inverter, fundamental frequency staircase modulation, multilevel inverter, three phase two level bridge inverter.

\section{Introduction}

Multilevel inverter (MLI) is a power electronics device which is mostly used in many industrial applications now a days. MLI has capable of providing desired AC voltage level at the output, using many lower level DC voltages as an input. MLI is mainly classified into three types. They are (1) Neutral Point clamped inverter (NPC), 2).Flying Capacitor inverter (FC),(3).Cascaded H-Bridge inverter(CHB). Different types of MLI circuit topologies and populous collection of control strategies are summarized in the literature[1]-[3].The main drawbacks of above topologies are, capacitor voltage balancing in the NPC, the output which is produced by FC is half of its input voltage, and large amount of separate dc supplies in CHB which are elaborated in the literature[4],[5].Aside from these three main topologies, alternative topologies like Multilevel DC link inverter are described in the literature[6]-[17].In recent times, the research area gives importance to hybrid multilevel and asymmetrical multilevel inverter topologies. The price and size of these topologies are diminished. And improve the accuracy seeing that fewer number of dc supplies, capacitors, switches and power electronics elements are used. Unequal dc supplies are used in hybrid multilevel inverters and this inverter consists of various multilevel configurations. Distinct Modulation techniques and power electronics components are required with this type of converter [18]-[19].Various topologies and distinct types of bidirectional switches were recommended for the purpose of improving the performance of typical single phase and three phase inverters [20]-[22].Contrast to unidirectional switch, bidirectional switch has ability to hold off the voltage and conduct the current in both direction. The proper control strategies are used in bidirectional switches in order to increase the performance of MLI in terms of compressing the total count of semiconductor devices, reducing the hold off voltage and producing the desired higher level output voltage[22]-[24].Depend on this technology ,this manuscript recommended a new topology for three phase five level inverter. Less number of power electronics components and insulated gate drive circuits are used in this inverter. Price and installation area are also decidedly minimized. By selecting appropriate degrees of utilized dc supplies we can obtain the required higher level voltage with adequate operation of fundamental frequency staircase modulation technique.

\section{Operation of novel topology}

Fig.(1) and (2) shows a classic configuration of three phase five level inverter which consists of typical three phase two level bridge inverter(Q1-Q6) .Three bidirectional switches (S1-S6, Dr1-Db2) two switches and two diode types are added with typical three phase two level bridge inverter. The operation of bidirectional switches is to hold off the higher voltage and ease the current flow to and from the midpoint (o). The fixed $4 \mathrm{~V}_{\mathrm{dc}}$ supply is given to the multilevel dc link inverter. Here two cascaded H-bridge (CHB) cells are used. These two CHB cells are having two unequal DC supplies. First cell has supply voltage of $\mathrm{V}_{\mathrm{dc}}$ and Second cell has supply voltage of $2 \mathrm{Vdc}$ which are connected in $(+, 0,-)$ bridge terminals. 


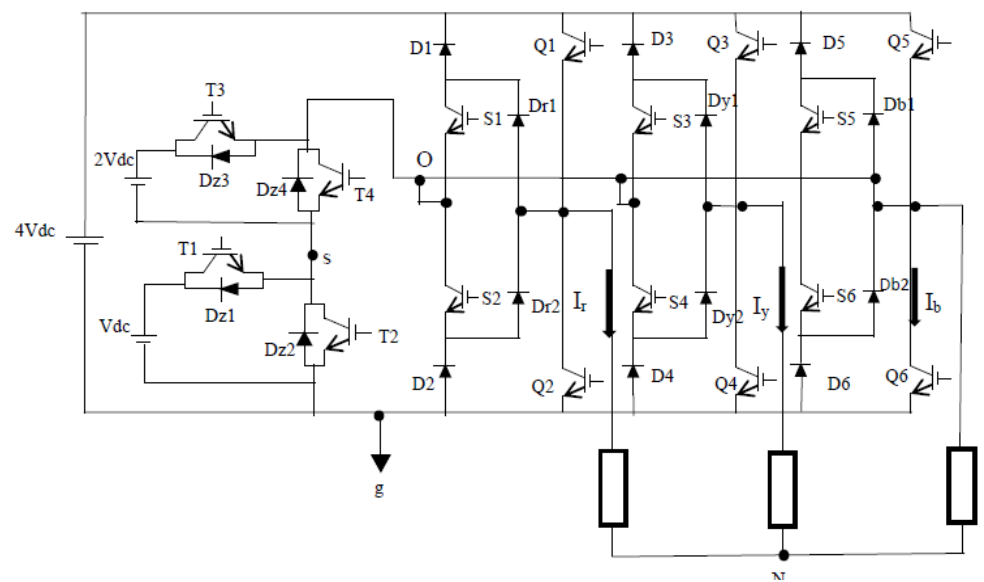

Fig.1 configuration of novel three phase five level inverter.

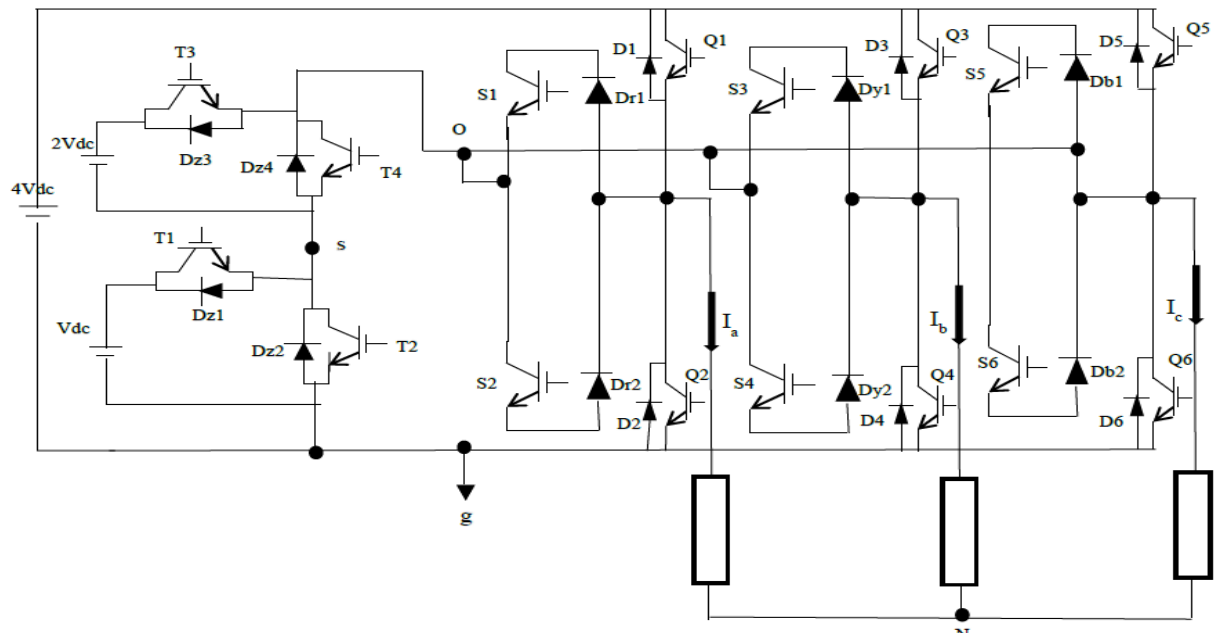

Fig.2 configuration of novel three phase five level inverter.

Depend on required voltage level, the total count of CHB cells are used. In this manuscript, the suggested inverter construct to produce a five level output voltage, hence here two CHB cells are used in series with two unequal dc supplies. The two switches from the each cell is turned ON and OFF under inverted condition. When $\mathrm{T} 1$ is turned $\mathrm{ON}$ the $\mathrm{V}_{\mathrm{dc}}$ of first cell supply is added $\mathrm{V}_{\mathrm{sg}}=+\mathrm{V}_{\mathrm{dc}}$ where $\mathrm{V}_{\mathrm{sg}}$ is the voltage at the node(s) with respect to ground (g), if T2 is turned $\mathrm{ON} \mathrm{V}_{\mathrm{sg}}=0$. In the same way, When $\mathrm{T} 3$ is turned $\mathrm{ON}$ the $2 \mathrm{Vdc}$ of second cell supply is added $\mathrm{V}_{\mathrm{os}}=+2 \mathrm{~V}_{\mathrm{dc}}$ where $\mathrm{V}_{\mathrm{os}}$ is the voltage at midpoint $(0)$ with respect to node $(\mathrm{m}) .4 \mathrm{Vdc}$ is the peak voltage rating of typical three phase two level bridge inverter(Q1-Q6) While 3Vdc is the peak voltage rating of three bidirectional switches(S1-S6). The first cell of CHB (T1, T2) has the peak voltage rating of $\mathrm{V}_{\mathrm{dc}}$ and the second cell of CHB (T3, T4) has the peak voltage rating of $2 \mathrm{Vdc}$. From phase $r$ the conducting status of the switches and inverter line to ground $\mathrm{V}_{\mathrm{rg}}$ are given in Table 1.

Table 1. Switching state $S_{\mathrm{r}}$ and inverter line to ground voltage $\mathrm{V}_{\mathrm{rg}}$

\begin{tabular}{|l|l|l|l|l|l|l|l|l|l|}
\hline $\mathrm{S}_{\mathrm{r}}$ & $\mathrm{Q} 1$ & $\mathrm{~S} 1$ & $\mathrm{~S} 2$ & $\mathrm{Q} 2$ & $\mathrm{~T} 1$ & $\mathrm{~T} 2$ & $\mathrm{~T} 3$ & $\mathrm{~T} 4$ & $\mathrm{~V}_{\mathrm{rg}}$ \\
\hline 4 & on & off & off & off & on & off & on & off & $+4 \mathrm{Vdc}$ \\
\hline 3 & off & on & on & off & on & off & on & off & $+3 \mathrm{Vdc}$ \\
\hline 2 & off & on & on & off & off & on & on & off & $+2 \mathrm{Vdc}$ \\
\hline 1 & off & on & on & off & on & off & off & on & $+\mathrm{Vdc}$ \\
\hline 0 & off & off & off & on & on & off & off & on & 0 \\
\hline
\end{tabular}

It is easier to define the inverter line-to-ground voltages $V_{\mathrm{rg}}, \mathrm{V}_{\mathrm{yg}}$, and $\mathrm{V}_{\mathrm{bg}}$ in terms of switching states $\mathrm{S}_{\mathrm{r}}, \mathrm{S}_{\mathrm{y}}$, and $\mathrm{S}_{\mathrm{b}}$ as,

$$
\left[\begin{array}{l}
V r g \\
V y g \\
V b g
\end{array}\right]=\frac{4 V d c}{M-1} *\left[\begin{array}{l}
S r \\
S y \\
S b
\end{array}\right] \text { (1) }
$$


Where $\mathrm{M}$ is the maximum number of voltage levels.

The switching state sequences of the suggested inverter is given in table II. The required balanced output voltages will be produced if the suggested inverter operates on the switching states which are given in the table 2. The proposed inverter have twenty four distinct modes with in a one cycle of output waveform .As stated in Table II, we know that the bidirectional switches are conduct only in eighteen modes. In all modes, there is only one bidirectional switch is in ON state.From this we can observe that the load current can be commutates through one switch and one diode. (For instance: in (410), the load current $\mathrm{I}_{\mathrm{y}}$ can flow in S3 and Dy1 or S4 and Dy2).Seeing that, few insulated bipolar transistors (IGBTs) share the similar switching gate signals, the suggested configuration decidedly granted in minimizing the switching devices and complexity of the system.

Table 2.Switching state sequence of the novel topology within one cycle

\begin{tabular}{|c|c|c|c|c|c|c|c|c|}
\hline $\mathrm{Sr} \mathrm{Sy} \mathrm{Sb}$ & Period[Ts] & $\begin{array}{l}\text { ON Switches } \\
\text { Leg r }\end{array}$ & $\begin{array}{l}\text { ON } \\
\text { Switches } \\
\text { Leg y }\end{array}$ & $\begin{array}{l}\text { ON } \\
\text { Switches } \\
\text { Leg b }\end{array}$ & $\begin{array}{l}\text { ON Switches } \\
\text { cascaded } \\
\text { half-bridge }\end{array}$ & Vrg & Vyg & Vbg \\
\hline 400 & $\mathrm{t} 1$ & Q1 & Q4 & Q6 & $\mathrm{T} 1, \mathrm{~T} 4$ & $4 \mathrm{Vdc}$ & 0 & 0 \\
\hline 410 & $\mathrm{t} 2$ & Q1 & $\mathrm{S} 3, \mathrm{~S} 4$ & Q6 & $\mathrm{T} 1, \mathrm{~T} 4$ & $4 \mathrm{Vdc}$ & Vdc & 0 \\
\hline 420 & t3 & Q1 & $\mathrm{S} 3, \mathrm{~S} 4$ & Q6 & $\mathrm{T} 2, \mathrm{~T} 3$ & $4 \mathrm{Vdc}$ & $2 \mathrm{Vdc}$ & 0 \\
\hline 430 & t4 & Q1 & $\mathrm{S} 3, \mathrm{~S} 4$ & Q6 & $\mathrm{T} 1, \mathrm{~T} 3$ & $4 \mathrm{Vdc}$ & $3 \mathrm{Vdc}$ & 0 \\
\hline 440 & t5 & Q1 & Q3 & Q6 & $\mathrm{T} 1, \mathrm{~T} 3$ & $4 \mathrm{Vdc}$ & $4 \mathrm{Vdc}$ & 0 \\
\hline 340 & t6 & $\mathrm{S} 1, \mathrm{~S} 2$ & Q3 & Q6 & $\mathrm{T} 1, \mathrm{~T} 3$ & $3 \mathrm{Vdc}$ & $4 \mathrm{Vdc}$ & 0 \\
\hline 240 & t7 & $\mathrm{S} 1, \mathrm{~S} 2$ & Q3 & Q6 & $\mathrm{T} 2, \mathrm{~T} 3$ & $2 \mathrm{Vdc}$ & $4 \mathrm{Vdc}$ & 0 \\
\hline 140 & t8 & $\mathrm{S} 1, \mathrm{~S} 2$ & Q3 & Q6 & $\mathrm{T} 1, \mathrm{~T} 4$ & $\mathrm{Vdc}$ & $4 \mathrm{Vdc}$ & 0 \\
\hline 040 & t9 & Q2 & Q3 & Q6 & $\mathrm{T} 1, \mathrm{~T} 4$ & 0 & $4 \mathrm{Vdc}$ & 0 \\
\hline 041 & $\mathrm{t} 10$ & Q2 & Q3 & S5,S6 & $\mathrm{T} 1, \mathrm{~T} 4$ & 0 & $4 \mathrm{Vdc}$ & Vdc \\
\hline 042 & $\mathrm{t} 11$ & Q2 & Q3 & S5,S6 & $\mathrm{T} 2, \mathrm{~T} 3$ & 0 & $4 \mathrm{Vdc}$ & $2 \mathrm{Vdc}$ \\
\hline 043 & $\mathrm{t} 12$ & Q2 & Q3 & S5,S6 & $\mathrm{T} 1, \mathrm{~T} 3$ & 0 & $4 \mathrm{Vdc}$ & $3 \mathrm{Vdc}$ \\
\hline 044 & $\mathrm{t} 13$ & Q2 & Q3 & Q5 & $\mathrm{T} 1, \mathrm{~T} 3$ & 0 & $4 \mathrm{Vdc}$ & $4 \mathrm{Vdc}$ \\
\hline 034 & $\mathrm{t} 14$ & Q2 & S3,S4 & Q5 & $\mathrm{T} 1, \mathrm{~T} 3$ & 0 & $3 \mathrm{Vdc}$ & $4 \mathrm{Vdc}$ \\
\hline 024 & $\mathrm{t} 15$ & Q2 & S3,S4 & Q5 & $\mathrm{T} 2, \mathrm{~T} 3$ & 0 & $2 \mathrm{Vdc}$ & $4 \mathrm{Vdc}$ \\
\hline 014 & $\mathrm{t} 16$ & Q2 & S3,S4 & Q5 & $\mathrm{T} 1, \mathrm{~T} 4$ & 0 & Vdc & $4 \mathrm{Vdc}$ \\
\hline 004 & $\mathrm{t} 17$ & Q2 & Q4 & Q5 & $\mathrm{T} 1, \mathrm{~T} 4$ & 0 & 0 & $4 \mathrm{Vdc}$ \\
\hline 104 & $\mathrm{t} 18$ & S1,S2 & Q4 & Q5 & $\mathrm{T} 1, \mathrm{~T} 4$ & Vdc & 0 & $4 \mathrm{Vdc}$ \\
\hline 204 & $\mathrm{t} 19$ & $\mathrm{~S} 1, \mathrm{~S} 2$ & Q4 & Q5 & $\mathrm{T} 2, \mathrm{~T} 3$ & $2 \mathrm{Vdc}$ & 0 & $4 \mathrm{Vdc}$ \\
\hline 304 & $\mathrm{t} 20$ & $\mathrm{~S} 1, \mathrm{~S} 2$ & Q4 & Q5 & $\mathrm{T} 1, \mathrm{~T} 3$ & $3 \mathrm{Vdc}$ & 0 & $4 \mathrm{Vdc}$ \\
\hline 404 & $\mathrm{t} 21$ & Q1 & Q4 & Q5 & T1,T3 & $4 \mathrm{Vdc}$ & 0 & $4 \mathrm{Vdc}$ \\
\hline 403 & $\mathrm{t} 22$ & Q1 & Q4 & S5,S6 & $\mathrm{T} 1, \mathrm{~T} 3$ & $4 \mathrm{Vdc}$ & 0 & $3 \mathrm{Vdc}$ \\
\hline 402 & $\mathrm{t} 23$ & Q1 & Q4 & S5,S6 & $\mathrm{T} 2, \mathrm{~T} 3$ & $4 \mathrm{Vdc}$ & 0 & $2 \mathrm{Vdc}$ \\
\hline 401 & $\mathrm{t} 24$ & Q1 & Q4 & S5,S6 & $\mathrm{T} 1, \mathrm{~T} 4$ & $4 \mathrm{Vdc}$ & 0 & Vdc \\
\hline
\end{tabular}

The inverter line-to-line voltage $\mathrm{V}_{\mathrm{ry}}, \mathrm{V}_{\mathrm{yb}}, \mathrm{V}_{\mathrm{br}}$ are related to $\mathrm{V}_{\mathrm{rg}}, \mathrm{V}_{\mathrm{yg}}$, and $\mathrm{V}_{\mathrm{bg}}$ by

$\left[\begin{array}{l}V r y \\ V y b \\ V b r\end{array}\right]=\left[\begin{array}{ccc}1 & -1 & 0 \\ 0 & 1 & -1 \\ -1 & 0 & 1\end{array}\right] *\left[\begin{array}{l}V r g \\ V y g \\ V b g\end{array}\right]$

The inverter line-to-neutral voltages $\mathrm{V}_{\mathrm{rN}}, \mathrm{V}_{\mathrm{yN}}$, and $\mathrm{V}_{\mathrm{bN}}$ may be expressed

$\left[\begin{array}{l}V r N \\ V y N \\ V b N\end{array}\right]=\frac{1}{3}\left[\begin{array}{ccc}2 & -1 & -1 \\ -1 & 2 & -1 \\ -1 & -1 & 2\end{array}\right] *\left[\begin{array}{l}V r g \\ V y g \\ V b g\end{array}\right]$

It is helpful to observe that the inverter voltages at terminals $r, y$, and b with respect to the midpoint (o) are given by

$\left[\begin{array}{l}\text { Vro } \\ \text { Vyo } \\ \text { Vboo }\end{array}\right]=\left[\begin{array}{l}\text { Vrg } \\ \text { Vyg } \\ V b g\end{array}\right]-\left[\begin{array}{l}\text { Vog } \\ \text { Vog } \\ \text { Vog }\end{array}\right]$

Where $\mathrm{V}_{\mathrm{og}}$ is the voltage at the midpoint $(\mathrm{o})$ with respect to ground $(\mathrm{g})$. $\mathrm{V}_{\mathrm{og}}$ normally oscillate between three distinct voltage values $\mathrm{Vdc}, 2 \mathrm{Vdc}$, and $3 \mathrm{Vdc}$ as follows:

$$
\mathrm{V}_{\mathrm{og}}= \begin{cases}V d c, & \text { If } S r+S y-S b \leq 5 . \\ 2 V d c, & \text { if } S r+S y-S b=6 . \\ 3 V d c, & \text { if } S r+S y-S b \geq 7 .\end{cases}
$$

For example, 13 sequent voltage steps are seen in $\mathrm{V}_{\mathrm{rN}}$ waveform as follows: $+8 \mathrm{Vdc} / 3,+7 \mathrm{Vdc} / 3$, $+6 \mathrm{Vdc} / 3,+5 \mathrm{Vdc} / 3,+4 \mathrm{Vdc} / 3,+2 \mathrm{Vdc} / 3,0,-2 \mathrm{Vdc} / 3,-4 \mathrm{Vdc} / 3,-5 \mathrm{Vdc} / 3,-6 \mathrm{~V} \mathrm{dc} / 3,-7 \mathrm{Vdc} / 3$, and $-8 \mathrm{Vdc} / 3$. From this we notice that all simulated output waveforms are attained at $\mathrm{t} 1=\mathrm{t} 2=\cdots=\mathrm{t} 24=0.02 / 24 \mathrm{~s}$. 


\section{DQ Transformation}

Clarke and Park transformations are used in high performance architectures in three phase power system analysis. Current and voltage are represented in terms of spacevector which is represented in a stationary reference frame. A general rotating reference frame has then been introduced. This frame is described by $\mathrm{d}$ and q axes .Clarke, Park and Inverse Park transformations have been described. Through the use of the Clarke transformation, the real and imaginary currents can be identified. The Park transformation is used to realize the transformation of those real and imaginary currents from the stationary to the rotating reference frame.

Fig.3 Block diagram of Clarke and Park transformation

\section{1 d-q Rotating Reference Frame}

Let us now convert $\mathrm{x}$ and $\mathrm{y}$ axes into $\mathrm{d}$ and $\mathrm{q}$ axes. Assume $\psi$ be a vector along $\mathrm{d}$-axis as shown in Fig. 6.3

In $(\alpha, \beta)$ plane,

In $(\mathrm{d}, \mathrm{q})$ plane,

$$
\psi=\psi \alpha+\psi \beta
$$

$$
\psi=\psi_{\mathrm{d}}+\psi_{\mathrm{q}}
$$

Angle between $(\alpha, \beta)$ and $(\mathrm{d}, \mathrm{q})$ is $\theta$. Then

$$
\cos \theta=\frac{\psi \alpha}{\psi \mathrm{d}}
$$

The following transformations are involved due to rotation of orthogonal d-q system

1. $\alpha$ - $\beta$ to d-q: Park transformation

2. $d-q$ to $\alpha-\beta$ : Inverse Park transformation

Transformation from $(\alpha, \beta)$ to $(d, q)$ is done by

$$
\left[\begin{array}{l}
\mathrm{d} \\
\mathrm{q}
\end{array}\right]=\left[\begin{array}{cc}
\cos \theta & \sin \theta \\
-\sin \theta & \cos \theta
\end{array}\right] *\left[\begin{array}{l}
\alpha \\
\beta
\end{array}\right]
$$

(or)

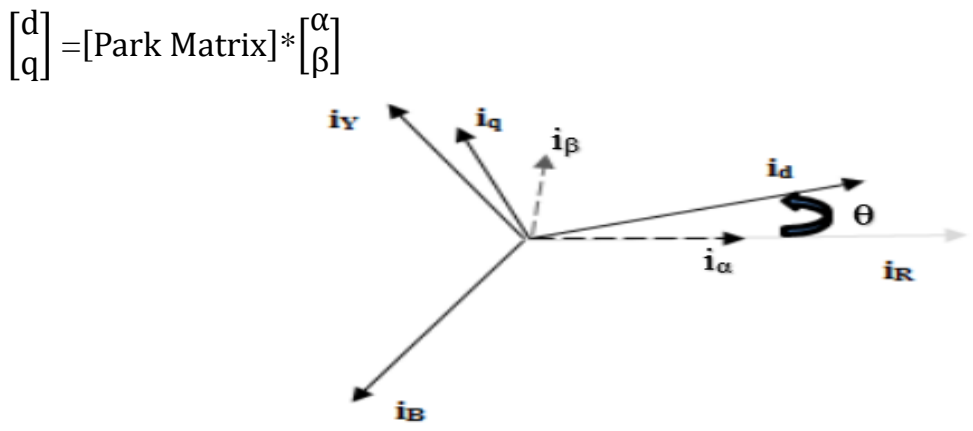

Fig.4 R-Y-B, $(\alpha, \beta)$ and $(d, q)$ current reference frames.

Voltages in Clarke plane can be obtained from phase voltages as follows

$$
\left[\begin{array}{l}
V \alpha \\
V \beta
\end{array}\right]=[\text { Clarke Matrix }] *\left[\begin{array}{l}
V R \\
V Y \\
V B
\end{array}\right]
$$

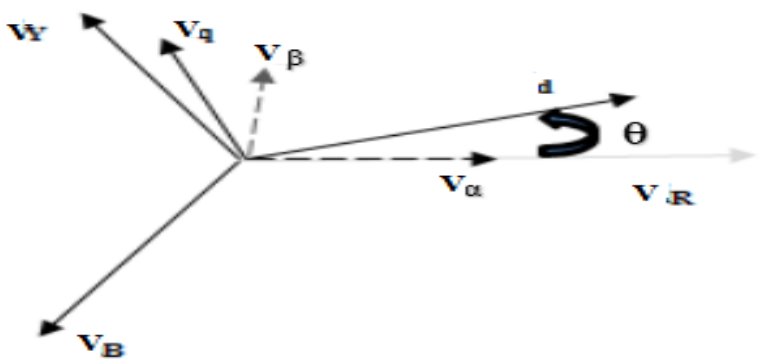

Fig.5 R-Y-B, $(\alpha, \beta)$ and $(\mathrm{d}, \mathrm{q})$ Voltage reference frames 
Voltages in Park plane can be obtained from Clarke plane voltages as follows

$$
\left[\begin{array}{l}
V d \\
V q
\end{array}\right]=[\text { Park Matrix }] *\left[\begin{array}{l}
V \alpha \\
V \beta
\end{array}\right]
$$

3.2 Space vector diagram for the proposed topology:

The below equations are used to derive the $\mathrm{d}$ and q voltage vectors to plot the space vector diagram of the new three phase inverter which is suggested in this manuscript.

$$
\begin{aligned}
\mathrm{V}_{\mathrm{q}} & =\frac{4 \mathrm{Vdc}}{3(\mathrm{~N}-1)}\left(2 \mathrm{~S}_{\mathrm{a}}-\mathrm{S}_{\mathrm{b}}-\mathrm{S}_{\mathrm{c}}\right) \\
\mathrm{V}_{\mathrm{d}} & =\frac{4 V \mathrm{dc}}{\sqrt{3}(N-1)}\left(\mathrm{S}_{\mathrm{c}}-\mathrm{S}_{\mathrm{b}}\right) \\
\mathrm{V} & =\mathrm{V}_{\mathrm{q}}-\mathrm{j} \mathrm{V}_{\mathrm{d}} .
\end{aligned}
$$

Switching states which are given in table 2, Fig. 6 shows the space vector diagram for the proposed topology

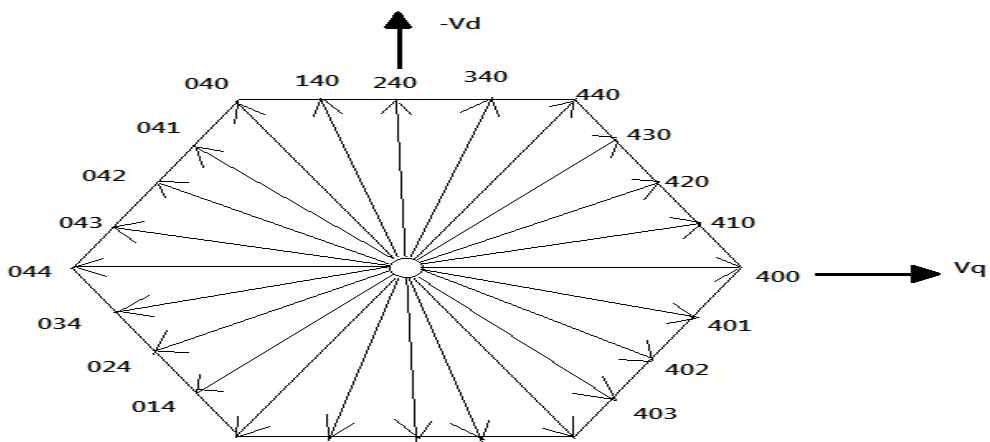

Fig.6 Space vector diagram for the proposed topology

\section{Switching algorithm}

To remove the unwanted harmonic components and to control the fundamental voltage, the Staircase modulation with selective harmonic elimination technique is used in the proposed topology .Newton-Rapson method is an iterative method which is used to solve the non-linear (M-1) equations. But the calculation of this method is very difficult and it takes more time to compute. This method needs a high performance controllers for real time applications these are the main drawbacks of this method. Hence the other method is used to produce appropriate switching gate signals of the proposed inverter. This method is used to control the new three phase proposed inverter. By using this method, the desired output voltage waveforms can be produced in terms of $S_{r}, S_{y}$, and $S_{b}$. The fundamental of the Staircase modulation technique can be described as following: The operation of the proposed inverter, within the full cycle of the inverter the switching states $S_{\mathrm{r}}, S_{\mathrm{y}}$, and $S_{\mathrm{b}}$ are decided immediately for a selected value of modulation index Ma. The on-time calculations of $S_{\mathrm{r}}, S_{\mathrm{y}}$, and $S_{\mathrm{b}}$ directly based on the immediate values of the inverter line-to-ground voltages. It is well known as the reference values of $\mathrm{V}_{\mathrm{rg}}, \mathrm{V}_{\mathrm{yg}}$, and $\mathrm{V}_{\mathrm{bg}}$ are given $\mathrm{b}$

$$
\begin{aligned}
{\left[\begin{array}{l}
V r g_{\text {_ref }} \\
V y g_{\text {_ref }} \\
V b g_{-} r e f
\end{array}\right]=\frac{M a * 4 V d c}{2} * } & {\left[\begin{array}{c}
\cos (w t) \\
\cos \left(w t-\frac{2}{3}\right) \\
\cos \left(w t+\frac{2}{3}\right)
\end{array}\right]+\frac{4 V d c}{2} *\left[\begin{array}{l}
1 \\
1 \\
1
\end{array}\right](17) } \\
& {\left[\begin{array}{c}
V r g_{-} r e f \\
V y g_{-} r e f \\
V b g_{-} r e f
\end{array}\right]=\frac{M a * 4 V d c^{2}}{2} *\left[\begin{array}{c}
\cos (w t) \\
\cos \left(w t-\frac{2}{3}\right) \\
\cos \left(w t+\frac{2}{3}\right)
\end{array}\right]+\frac{4 V d c}{2} }
\end{aligned}
$$

$$
\left[\begin{array}{l}
S r \\
S y \\
S b
\end{array}\right]=\left(\frac{M-1}{4 V d c} *\left[\begin{array}{c}
V r g_{-} r e f \\
V y g_{-} r e f \\
V b g \_r e f
\end{array}\right]\right) .
$$

Contrast to staircase modulation with selective harmonic method, the proposed modulation method requires fewer time and needs only easy calculations. The inverter's operating switching states $S_{r}, S_{y}$, and $S_{b}$ and appropriate switching gate signals depend on the proposed modulation method. From this we know that the switching gate signals are produced within twenty four distinct modes starting from (044) to (034). 


\section{Comparison study}

To test the performance of suggested configuration, the novel topology is compared with the typical multilevel three phase five level inverter topologies such as FC, CHB and NPC. It is proved that the novel three phase five level inverter requires less number of power electronics components when compared with conventional topologies with same number of voltage stages. For the five level output voltages the Table 3 explains the required number of dc voltage supplies, switches, clamping diodes,control signals and balancing capacitors of the novel three phase $\mathrm{M}$ level inverter compared with conventionalinverters such as $\mathrm{CHB}, \mathrm{Fc}$ and NPC, and Table 4 explains the required voltage rating of conventional and proposed topology.

Table 3.Comparison of three phase five level conventional topologies with novel three phase five level inverter

\begin{tabular}{|l|l|l|l|c|}
\hline Converter type & NPC & FC & CHB & Proposed inverter \\
\hline Switches & $6(\mathrm{M}-1)$ & $6(\mathrm{M}-1)$ & $6(\mathrm{M}-1)$ & $\sqrt{8 M-15}+11$ \\
\hline Gate drives & $6(\mathrm{M}-1)$ & $6(\mathrm{M}-1)$ & $6(\mathrm{M}-1)$ & $\sqrt{8 M-15}+8$ \\
\hline Diodes & $6(\mathrm{M}-1)$ & $6(\mathrm{M}-1)$ & $6(\mathrm{M}-1)$ & $\sqrt{8 M-15}+11$ \\
\hline Clamping diodes & $6(\mathrm{M}-2)$ & 0 & 0 & 0 \\
\hline Dc supplies & $\mathrm{M}-1$ & $\mathrm{M}-1$ & $3(\mathrm{M}-1) / 2$ & $1+[\sqrt{8 M-15}-1 / 2]$ \\
\hline $\begin{array}{l}\text { Clamping } \\
\text { capacitors }\end{array}$ & 0 & $3(\mathrm{M}-1)$ & 0 & 0 \\
\hline Control signals & $6(\mathrm{M}-1)$ & $6(\mathrm{M}-1)$ & $6(\mathrm{M}-1)$ & $\sqrt{8 M-15}+8$ \\
\hline
\end{tabular}

Table 4.Proposed and the existing topologies rating requirements per level $\mathrm{N}$

\begin{tabular}{|c|c|c|c|c|c|c|c|c|}
\hline \multirow[t]{2}{*}{$\begin{array}{l}\text { Novel three } \\
\text { phase five level } \\
\text { inverter }\end{array}$} & \multirow[t]{2}{*}{$\begin{array}{l}\text { Main bridge } \\
\text { Q1-Q6 } \\
\text { Da1-Dc2 }\end{array}$} & \multirow{2}{*}{$\begin{array}{l}\text { Bidirectional } \\
\text { switches } \\
\text { S1 to S6 } \\
\text { D1 to D6 }\end{array}$} & \multicolumn{2}{|c|}{$\begin{array}{l}\text { Cascaded Half- } \\
\text { Bridge switches T1 } \\
\text { to T4 }\end{array}$} & \multirow{2}{*}{$\begin{array}{l}\text { Converter type } \\
\text { Switches } \\
\text { Voltage rating }\end{array}$} & \multirow{2}{*}{$\begin{array}{l}\mathrm{NPC} \\
\mathrm{V}_{\mathrm{dc}}\end{array}$} & \multirow{2}{*}{$\begin{array}{l}\mathrm{FC} \\
\mathrm{V}_{\mathrm{dc}}\end{array}$} & \multirow{2}{*}{$\begin{array}{l}\mathrm{CHB} \\
\mathrm{V}_{\mathrm{dc}}\end{array}$} \\
\hline & & & $1^{\text {st }}$ cell & $2^{\text {nd }}$ cell & & & & \\
\hline \multirow[t]{2}{*}{$\begin{array}{l}\text { Component } \\
\text { voltage rating }\end{array}$} & \multirow[t]{2}{*}{$(\mathrm{N}-1) \mathrm{V}_{\mathrm{dc}}$} & \multirow[t]{2}{*}{$(\mathrm{N}-2) \mathrm{V}_{\mathrm{dc}}$} & \multirow[t]{2}{*}{$\mathrm{V}_{\mathrm{dc}}$} & \multirow[t]{2}{*}{$2 V_{d c}$} & $\begin{array}{l}\text { Clamping diode } \\
\text { voltage rating }\end{array}$ & $\mathrm{V}_{\mathrm{dc}}$ & 0 & 0 \\
\hline & & & & & $\begin{array}{l}\text { Clamping } \\
\text { capacitor voltage } \\
\text { rating }\end{array}$ & 0 & $\mathrm{~V}_{\mathrm{dc}}$ & 0 \\
\hline
\end{tabular}

\section{Simulation and Results}

To ensure the workability of the proposed topology, the inverter was executed. The inverter which isshown in Fig. 1 and Fig. 2 was investigated under $\mathrm{V}_{\mathrm{dc}}=22.5 \mathrm{~V}$ in the first cell, $2 \mathrm{~V}_{\mathrm{dc}}=45 \mathrm{~V}$ in the second cell and $4 \mathrm{~V}_{\mathrm{dc}}=90 \mathrm{~V}$. The degree of the fixed dc supply is determined as $\mathrm{V}_{\mathrm{fix}}=4 \mathrm{~V}_{\mathrm{dc}}=90 \mathrm{~V}$. Fixed three-phase series resistive-inductive load $(23 \Omega-3 \mathrm{mH} / \mathrm{Phase})$ in star connection was used.

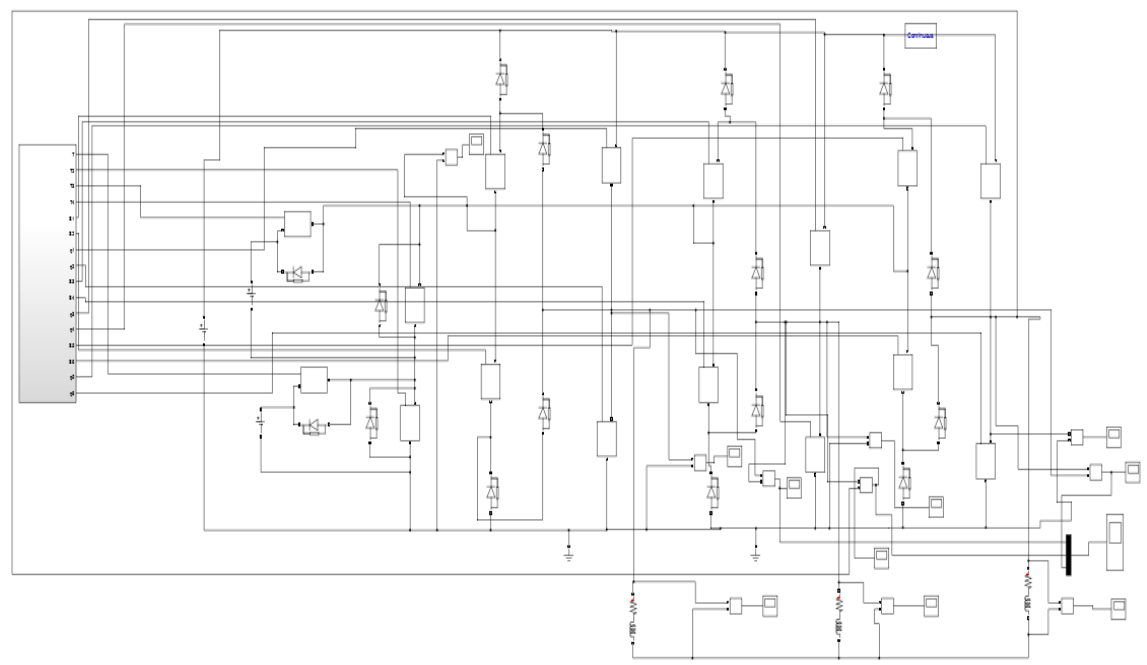

Fig.7 Simulink model of novel three phase five level inverter (configuration 1) 


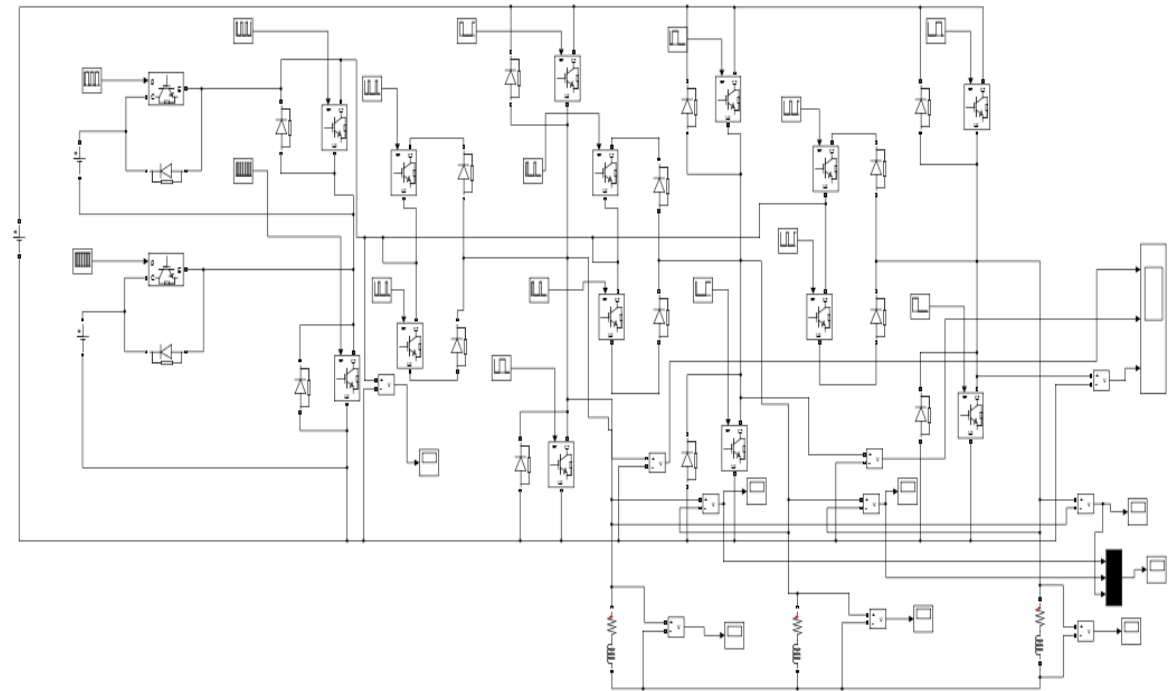

Fig.8 Simulink model of novel three phase five level inverter (configuration 2)
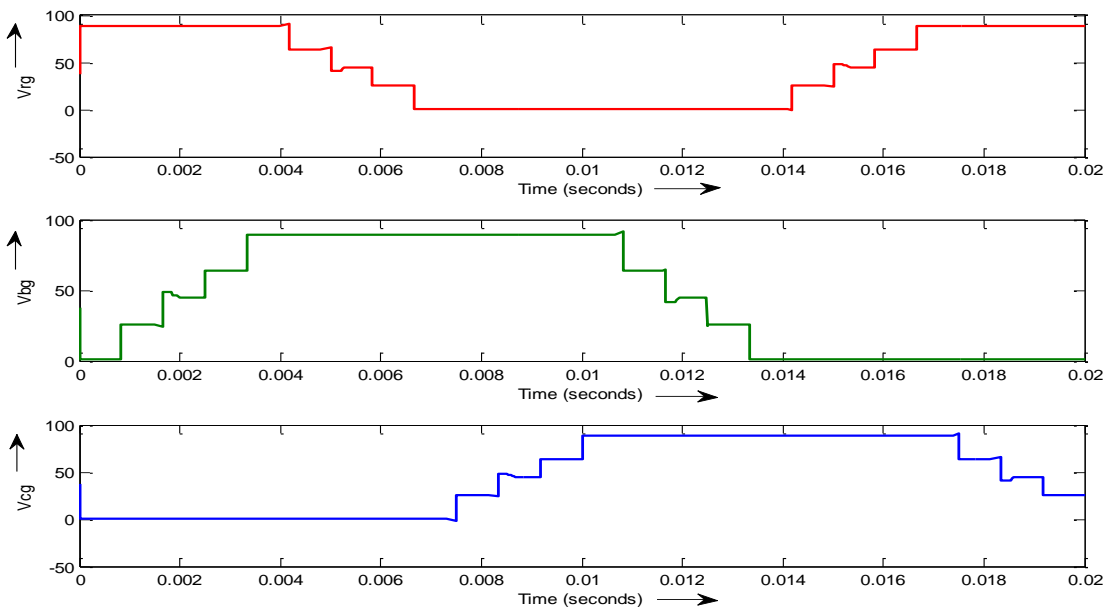

Fig.9 Simulated output waveforms of inverter line to ground voltages $V_{\mathrm{rg}}, \mathrm{V}_{\mathrm{yg}}, \mathrm{V}_{\mathrm{bg}}$
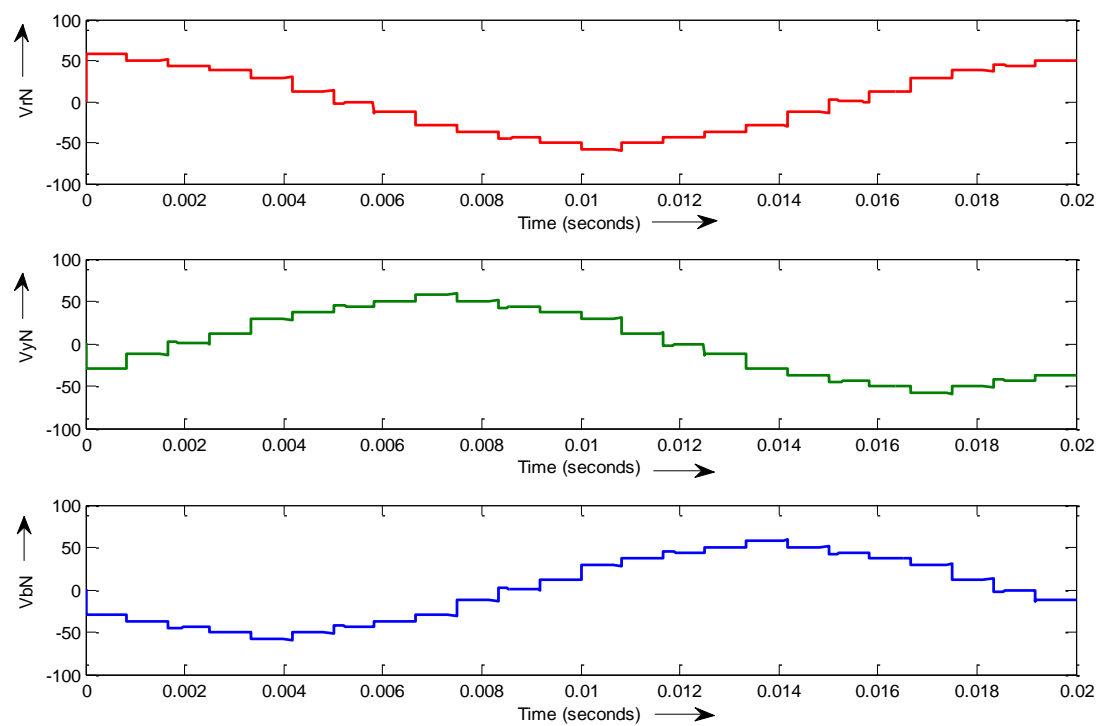

Fig.10 Simulated output waveforms of Phase voltages $V_{r N}, V_{y N}, V_{b N}$ 

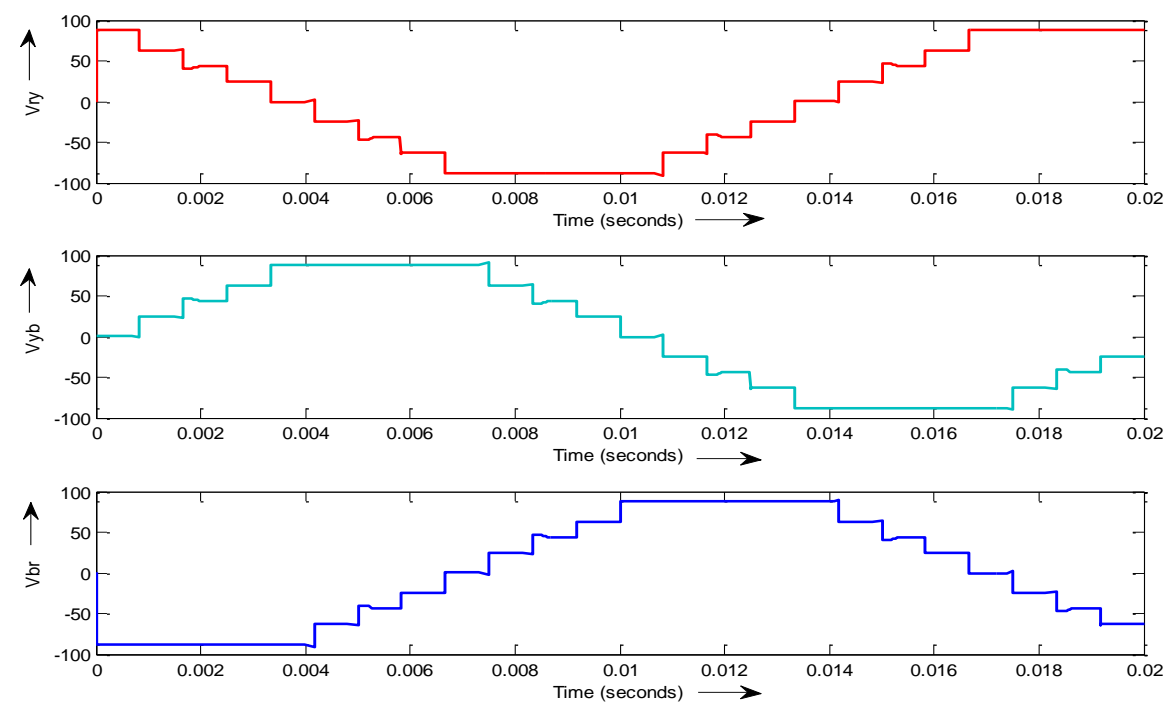

Fig.11 Simulated output waveforms of Line voltages $\mathrm{V}_{\mathrm{ry}}, \mathrm{V}_{\mathrm{yb}}, \mathrm{V}_{\mathrm{br}}$

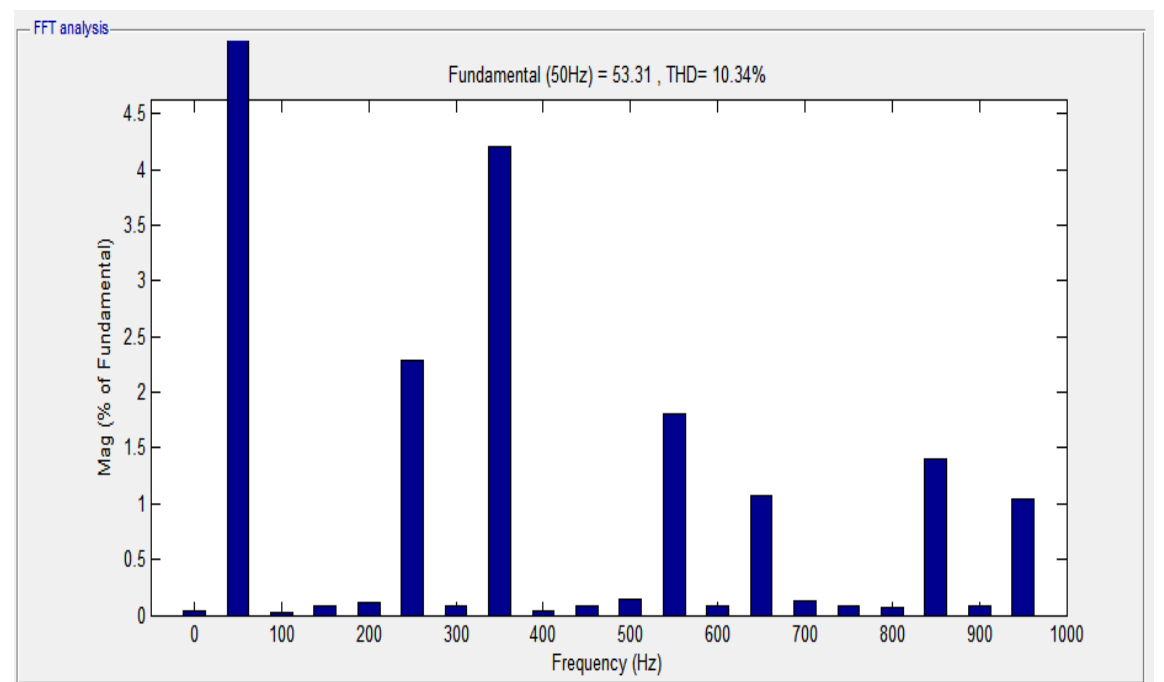

Fig.12 Total Harmonics Distortion of novel three phase five level phase voltage shows $10.34 \%$

\section{Conclusion}

The novel topology of three phase five level inverter was introduced. The proposed configuration was obtained from minimized number of power electronics elements. Therefore, the novel topology results in reduction of installation area, price and obtained lower \%THD. Hence subsequent work in future may include an extension to high level with other recommended methods.

\section{Acknowledgement}

First and foremost, we would thank god almighty for blessing us with enthusiasm,courage,knowledge and energy to help us finish our M.E final year project. We thankful to our management for support and guidance and encouragement in making this project possible. Our sincere thanks to all the lectures who helped us in many ways, gave valuable advises and make our journey easy.

\section{References}

[1] J. Rodriguez et al., "Multilevel inverters: A survey of topologies, controls,and applications," IEEE Trans. Ind. Electron., vol. 49, no. 4, pp.724-738,Aug.2002.

[2] L. G. Franquelo et al., "The age of multilevel converters arrives," IEEE Ind. Electron. Mag., vol. 2, no. 2, pp. 28-39, Jun. 2008.

[3] I. Colak et al., "Review of multilevel voltage source inverter topologies and control schemes," Energy Convers. Manage., vol. 52, pp. 1114- 1128,2011.

[4] J. Rodriguez et al., "Multilevel converters: An enabling technology for high-power applications," Proc. IEEE, vol. 97, no. 11, pp. 1786- 1817,Nov. 2009 
[5] J. Rodriguez et al., “A survey on neutral-point-clamped inverters,” IEEE Trans. Ind. Electron., vol. 57, no. 7, pp. 2219-2230, Jul. 2010.

[6] S. Gui-Jia, “Multilevel DC-link inverter,” IEEE Trans. Ind. Appl., vol. 41,no. 3, pp. 848-854, May/Jun. 2005.

[7] P. Fang Zheng, "A generalized multilevel inverter topology with self voltage balancing," IEEE Trans. Ind. Appl., vol. 37, no. 2, pp. 611- 618,Mar/Apr.2001.

[8] J. A. Ferreira, "The multilevelmodular DC converter," IEEE Trans. Power Electron., vol. 28, no. 10, pp. 4460-4465, Oct. 2013.

[9] K. Ilves et al., "A new modulation method for the modular multilevel converter allowing fundamental switching frequency," IEEE Trans.Power Electron.,vol.27,no.8,pp.3482-3494,Aug.2012.

[10] W. Yong andW. Fei, "Novel three-phase three-level-stacked neutral point clamped grid-tied solar inverter with a split phase controller," IEEE Trans.Power Electron.,vol. 28, no. 6, pp. 2856-2866, Jun. 2013.

[11] Y. Yuanmao and K. W. E. Cheng, "A family of single-stage switchedcapacitor-inductor PWM converters," IEEE Trans. Power Electron.,vol. 28, no. 11, pp. 5196-5205, Nov. 2013.

[12] P. Roshankumar et al., "A five-level inverter topology with single-DC supply by cascading a flying capacitor inverter and an Hbridge," IEEETrans. Power Electron., vol. 27, no. 8, pp. 3505-3512, Aug. 2012.

[13] N. A. Rahim et al., "Transistor-clamped H-bridge based cascaded multilevel inverter with new method of capacitor voltage balancing," IEEETrans. Ind. Electron., vol. 60, no. 8, pp. 2943-2956, Aug. 2013.

[14] I. Abdalla et al., "Multilevel DC-link inverter and control algorithm toovercome the PV partial shading," IEEE Trans. Power Electron., vol.28,no. 1, pp. 14-18, Jan. 2013.

[15] Z. Li et al., "A family of neutral point clamped full-bridge topologies for transformer less photovoltaic grid-tied inverters," IEEE Trans. PowerElectron., vol. 28, no. 2, pp. 730-739, Feb. 2013.

[16] L. Jun et al., "A new nine-level active NPC (ANPC) converter for grid connection of large wind turbines for distributed generation," IEEE Trans.Power Electron., vol. 26, no. 3, pp. 961-972, Mar. 2011.

[17] L. Zixin et al., "A novel single-phase five-level inverter with coupled inductors," IEEE Trans. Power Electron., vol. 27, no. 6, pp. 2716-2725,Jun. 2012.

[18] S. Mariethoz, "Systematic design of high-performance hybrid cascaded multilevel inverters with active voltage balance and minimum Switching losses," IEEE Trans. Power Electron., vol. 28, no. 7, pp. 3100-3113, Jul.2013.

[19] M. Saeedifard et al., "Operation and control of a hybrid seven-level converter,'IEEE Trans. Power Electron., vol. 27, no. 2, pp. 652-660, Feb.2012.

[20] P. Sung-Jun et al., "A new single-phase five-level PWM inverter employinga deadbeat control scheme," IEEE Trans. Power Electron., vol. 18,no. 3, pp. 831-843, May 2003.

[21] C. Klumpner and F. Blaabjerg, "Using reverse-blocking IGBTs in powerconverters for adjustable-speed drives," IEEE Trans. Ind. Appl., vol. 42,no. 3, pp. 807-816, May/Jun. 2006.

[22] E. A. Mahrous et al., "Three-phase three-level voltage source inverter with low switching frequency based on the two-level inverter topology," Electr.Power Appl., vol. 1, pp. 637-641, 2007.

[23] S. Suroso and T. Noguchi, "Multilevel current waveform generation usinginductor cells and H-bridge current-source inverter," IEEE Trans. PowerElectron., vol. 27, no. 3, pp. 1090-1098, Mar. 2012.

[24] M. F. Kangarlu and E. Babaei, "A generalized cascaded multilevel inverter using series connection of sub multilevel inverters," IEEE Trans. PowerElectron., vol. 28, no. 2, pp. 625-636, Feb. 2013. 